\title{
A Program Based on the Successful Intelligence Theory for Developing Motivation among Secondary Schoolers*
}

\author{
Prepared by \\ Marwa Gharib Ebrahim Mohamed
}

\section{Introduction}

The purpose of the current study was to develop a program based on Successful Intelligence Theory to improve motivation of secondary schoolers. It also aimed at measuring the effectiveness of the proposed program. A pilot study was conducted in order to confirm the existence of a problem in secondary stage students' motivation for writing.

Context of the Problem

Motivation plays an important role in EFL teaching and learning situations. Dornyei (2001:12) states "motivation represents a basic characteristic of the human nature, therefore; a large number of teachers and researchers affirm the necessary and important role it plays in determining whether the learning situation is successful or unsuccessful."

One of the most important factors for success in learning in particular and life in general is sticking to an aim to increase motivation. Motivation is a widely complicated term, which is largely used in everyday life situations . As Dörnyei, Csizér and Németh (2006:115) claim "Certain circumstances are seriously needed to be provided in order to learn a second language (L2) successfully, so many instructors and researchers agree that motivation is an essential factor for learning achievement. Therefore, identifying and investigating $\mathrm{L} 2$ motivation and determining the basic features of motivated learners occupy an important position in the research plans of applied linguists and TEFL specialists."

According to the above mentioned source (Ibid: 120) "the integrative motive consists of many connected elements. These include attitudinal, goal-directed, motivational sides and self estimate level. This forms integrativeness, tendency towards the learning process, assessment of second language(L2) instructor and the L2 program, and towards 'motivation as a whole. Dornyei, Csizer and

* Research emerged from a PhD thesis 
Nemeth(2006:130) define motivation concept as "a latent concept comprising the desire to learn and the L2motivation intensity, and attitudes towards learning the L2.Therefore, integrativeness and Instrumentality are the most important factors when dealing with the term of language motivation in accordance with the conclusions reached by Dornyei, Csizer and Nemeth. Linguistic Self-Confidence, introduced into L2 motivation as Dörnyei, Csizér and Németh referred to, is another important controlling factor in second language motivation. Teaching language and improving quality (TL+Q) project was developed by Segura \&Marques etal (2012:31) .It identified three major constituting elements, which lead to the refinement and improvement of learning and educational system quality which are: The quality growth rate at school, atmosphere inside classes and applying creative and ingenious motivating learning and teaching methods.

In their project, Segura \&Marques et al (2012:14) assert the necessity of "moving from traditional ways of teaching to new ways of teaching in order to increase the students' motivation for learning. Using group work instead of classical class teaching methods. Learning to apply in life situations instead of learning for reproduction in tests. Even the teacher role was recommended to move from being an expert to being a coach. Subject Teaching Tasked-based, should be changed to be problem-solving Projects. Differentiation as a goal not considering standardization as a goal."

In the same way Brophy (2009:55) introduces four factors influencing and increasing students' motivation. These factors are: (1)motivating them by modeling,(2) identification of their ambitions,(3) direct instruction and (4) being deeply affected by social symbols such as parents or teachers. For improving communication inside the classroom, He(2009) confirms dividing students into small groups composed of two to four students as the first block of the main classroom format. This principle is based on that group size deeply affects students' interaction and contribution in oral activities inside the classroom. In big groups, many students who are shy will tend to be silent and let their other colleagues do the talking instead of them. On the contrary, being in small group students take part in the group work in order to finish the task. Labor's division will happen through assigning task and roles for each student. Besides, small student groups allows and encourages a quantitative change in students' attitudes to take place.

Pilot study 
To identify the problem of the current research and the deficiencies in the present situation as regards motivation among secondary schoolers, Ten EFL secondary stage teachers at El-Farouk Omar secondary school for boys were asked about their motivation towards English in general and writing in particular.

Statement of the Problem:

In the light of the results of the previous studies related to motivation at the secondary stage, the problem of research can be stated as follows: "secondary school students lack motivation towards English in general and EFL writing in particular " as their motivation level is low. The current research sought to enhance secondary stage students' motivation

Therefore; the current research sought to find answers to the following main questions:

1- What are the features of a Successful Intelligence Theory based program that may contribute in enhancing motivation towards English among secondary schoolers?

2-How far is the program effective in improving motivation among secondary schoolers?

Delimitations of the research

The research was delimited to:

1. A group of first year secondary stage students in Ismailia.

Method of the study

Participants \& Research Design:

participants of this research were 62 first year secondary stage students, who were divided into two groups: one is experimental and the second one is a control group. The researcher adopted the quasi experimental design in order to test the effectiveness of the suggested program.

Instruments:

The researcher developed one main instrument in order to fulfill the major objective of the study; which is a motivation scale.

\section{Motivation Scale}

A motivation scale was prepared after reviewing related literature and previous studies dealt with motivation in general and motivation for English language in particular.from Bruning and Horn (2000) Zhang (2007); Ghaith and Shaaban(2008); Zhang and Guo's study (2012); Lightbown and Spada (2013); Troia et al. (2013) ; Veronica et al (2014). Then the motivation scale was prepared in its initial form. The scale consists of three main 
dimensions. The first one ( Importance of studying English language during secondary stage it included eleven items). The second dimension (Role of studying English language and making communication in English easier) includes only three items. The third one is (Motivation for using English in life situations; consists of seven items).

Validity of the Motivation Scale

The scale was submitted to a group of EFL specialists to validate it .After filtering the feedback and recommendations given by the jury members, the final version of the scale was elaborated as follows:

اهمية دراسة اللغة الانجليزية بالمرحلة الثانوية

1-IImportance of iM Importance of English la

a. Studying English helps me better understand and appreciate English literature.

تساعدنى دراستى للغة الانجليزية فى فهم و تزوق الادب الاتجليزى بشكل افضل.

b. Studying English helps me meet and converse with more and different

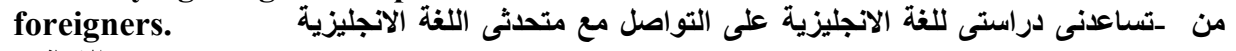
الاجانب.

c. Studying English will help me to learn about other cultures. -تساعدنى دراسنى للغة الاتجليزية فى التعرف على ثقافات غربية مختلفة .

d. Studying English will not help me to understand the Western culture heritage. لن تساعدنى دراستى للغة الانجليزية على تعلم الموروث الثقافى الغربى.

e. Learning English is not important for the economic development of the world. لا يعد تعلم اللغة الانجليزية امرا هاما فى التطور الاقتصادى العالمى.

f. Learning English will not make me think about the words and ideas that I learned in the class.

لا يوجهنى تعلم اللغة الانجليزية الى التفكير فى الكلمات و الجمل التى ادرسها.

g. Learning English is important for getting a suitable job in the future. تعلم اللغة الانجليزية مهم فى الحصول على وظيفة مناسبة مستقبلا.

h. Learning English is important because I need it for university. - تعلم اللغة الانجليزية مفيذ و مهم للار اسة بالجامعة.

i-I practice pronunciation at class only to get good grades in my English exams.

اقوم بممارسة النطق باللغة الانجليزية داخل الفصل فقط من اجل الحصول على درجات مرتفعة فى اختبارات اللغة الانجليزية.

j.I think that knowing English wouldn't help me to travel abroad in the future. اعتقد ان تعلمى للغة الانجليزية لن يساعدنى فى السفر للخارج مستقبلا.

k.I think that knowing English would help me become a more knowledgeable person.

اعثقد ان تعلم اللغة الاتجليزية سوف يجعنى شخصا مثقفا.

2-Role of studying English language and making communication in English easier.

دور دراسة اللغة الانجليزية فى تيسير التواصل باللغة الاتجليزية.

m. Learning English is important for communicating in English when I travel to English-speaking countries.

تعلم اللغة الانجليزية هام لأنه يمكنى من التواصل عند السفر للاول المتحثثة للغة الانجليزية.

n. By improving my pronunciation, I hope to be able to communicate more 


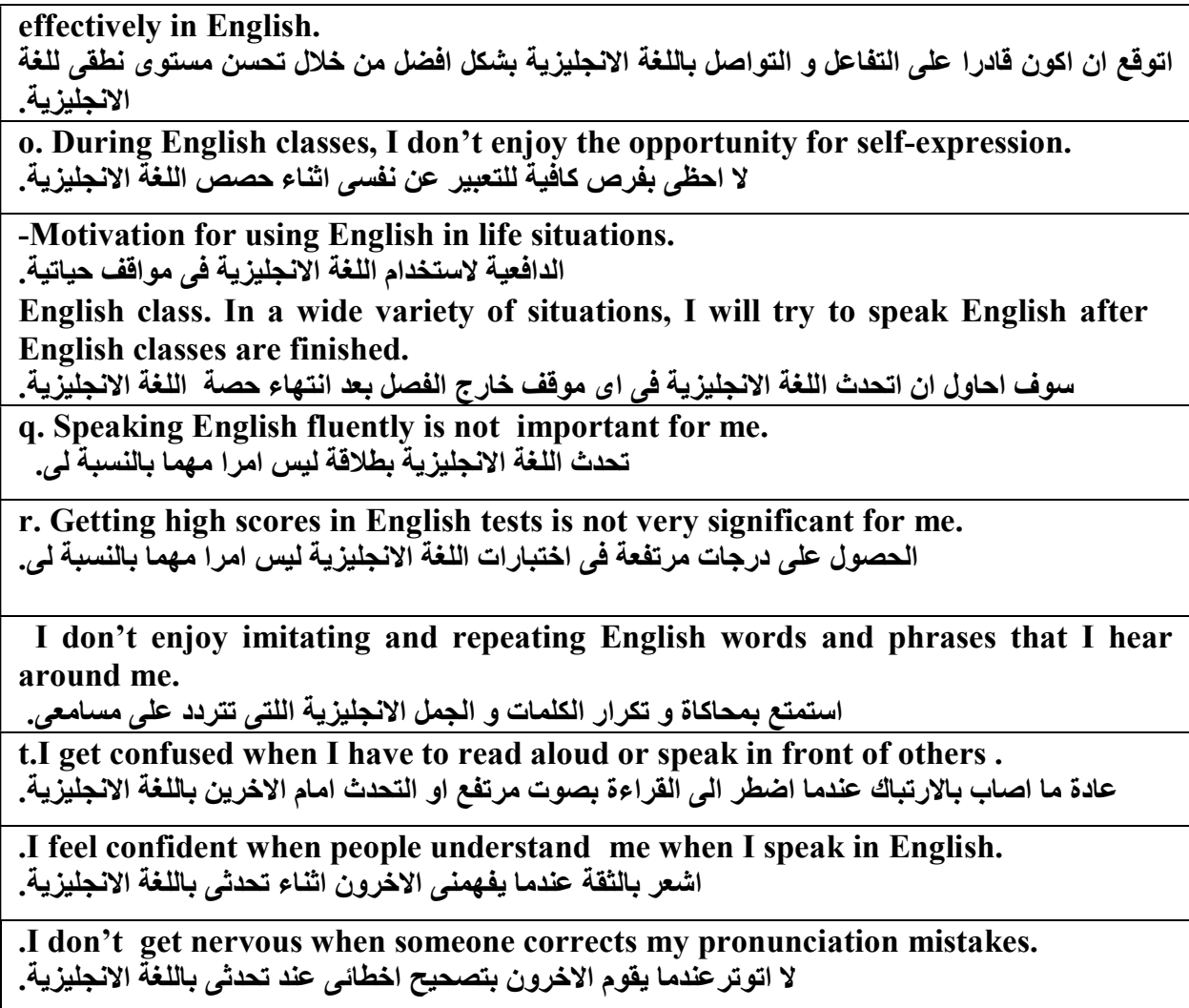

All the previous twenty one items ranged from strongly agree, agree, and disagree. Students were required to read each item carefully, then decide the suitable response that reflects their motivation towards English.

For identifying the needed time for responding to items of the scale, (25) students were chosen randomly from first year secondary schoolers of El-Zohour secondary school in Ismaillia. The scale was answered by those students, who were not included either in the experimental group or the control one. The time was determined through calculating the mean time taken by the participants for finishing responding to the whole scale. It was 30 minutes.

Concerning scoring the motivation scale, a score ranged from three (3) points to one (1) were set for each response. So, the total score of the scale was 63 points.

The scale reliability was measured by Alpha Cronbach's formula. The scale was administered to a pilot sample of (10) secondary schoolers .It was found $(0,73)$ which refers that the scale is highly reliable, indicating the high internal coherence of the scale. The Successful intelligence Theory Based Program (SITBP) 
The program was designed for developing creative writing skills and motivation towards English among first year secondary schoolers.

A. Objectives of the SITBP

By the end of the experimentation, secondary schoolers will be able to :

1.Write creatively as a result of developing their creative writing skills.

2.be highly motivated towards English.

B. The principles of the SITBP

The major principles of Successful Intelligence Theory Based Program were collected through reviewing the related literature dealt with the successful intelligence theory, activities and its practical applications. Considering all the basics obtained from those sources; the principles can be summarized as follows:

1. Encouraging students to formulate and ask questions, because questioning should be made a part of the daily classroom exchange, not just to answer questions.

2. Providing students with step by step monitoring and feedback.

3. Encouraging students to evaluate through asking them to comment on the strengths and weaknesses of their own work and others'.

4. Asserting the importance of constructive critique.

5. Asking students to explain why it is better than the existing ones, if they do some creative work.

6. Giving students time to think creatively, rewarding creativity and creative efforts.

7. Helping students imagine their viewpoints.

8. Helping students to explore their mistakes in order to correct them.

9. Assigning responsibility in students help them to understand their thinking processes, criticize themselves and take pride in their best work.

10. Encouraging students to analyze the offered information, to evaluate the value of what they learned and compare many situations or problems.

11. Capitalizing the students' strengths and compensating for their weaknesses.

C. The Duration of administering the SITBP

Experimentation lasted for six weeks in the first semester of the academic year 2017-2018 from $9^{\text {th }}$ of November to the $20^{\text {th }}$ of December consisting of seventeen sessions. 
D. The teaching Aids

1-Handouts( including titles of paragraphs and pictures for warming up activities)

2-PowerPoint presentations .

E. Materials for the SITBP

The instructional content of the program consisted of titles of paragraphs which were taken from the Student's book (Hello!6). They were used with the experimental group using the SITBP. The control group was taught through the traditional teaching method.

F. Description of the SITBP

a. The first session was dedicated to orientation,for making the first year secondary scholers aware of the essence and importance of creative writing .Also the successful intelligence theory implications are novel for them; so it was necessary to mentally and emotionally preparing them well for the tasks they are to be involved. For achieving this goal the researcher worked for creating a friendly atmosphere by a simple presentation; illustrating for them that the main aim for this experiment is helping them to write creatively.

b. In the second session, the motivation scale was administered to the two groups .

c. Session three included adminstering the prepared activities and tasks for developing the first creative writing skill. Firstly, the intended learning outcome was demonstrated; it was developing their abilities for generating as much flexible, original and valuable ideas as possible. They were asked to write a paragraph predicting changes that are likely to occur in their lives if they were given a scholarship to continue their education abroad. After finishing the activity; they were required to identify the key ideas taking out the grammatical and functional mistakes they did. Written paragraphs were reciprocated among then to analyze the mistakes and for correcting them. The last step was to e-write the same paragraph avoiding the discovered errors.

Data Analysis and Discussion

After collecting the data, they were analyzed using the t-test, and the results were discussed as follows.

The following statistical methods were used to confirm the hypotheses. 
1-t-Test Paired to verify the study hypotheses, i.e. to test the significance of the differences between the pre-and the postapplications.

2-Effect Size was used for testing the descriptive hypothesis.

4.2 Comparison between the experimental group and the control group prior to starting the experiment.

Before administering the SITBP, it was necessary to make sure that there was no difference between the mean scores of the two groups (the experimental and the control) on the motivation scale.

Table (1) $T$ test Value for the differences between the experimental and the control groups mean scores on the creative writing skills test prior to starting the experiment

\begin{tabular}{|l|l|l|l|l|l|l|}
\hline $\begin{array}{l}\text { Creative } \\
\text { Writing } \\
\text { Skills Test }\end{array}$ & Groups & No & Mean & S.D & t & Sig at 0,05 \\
\hline Pre-test & Experimental & 31 & 9,67 & 6,42 & .97 & $\mathbf{0 , 3}$ (Not Sig) \\
\hline & Control & 31 & 11,12 & 5,26 & .97 & $\mathbf{0 , 3}$ (Not Sig) \\
\hline
\end{tabular}

Findings

Findings are displayed in terms of the hypotheses of the study as

follows:

Hypothesis (1)

Hypothesis one stated "There is a statistically significant difference between the mean scores of the experimental and the control groups at $(0.05)$ level in the post administration of motivation scale (for the overall dimensions) after the administration of the post scale in favor of the experimental group. In this respect, the mean scores, standards deviations and $T$-Value for independent variables were estimated to measure the statistical differences between the two groups. Table (1) shows the differences between the mean scores standards deviations-Value, Effect size (Eta-Squared) for the differences after the post application of the motivation scale . 
Table (2) Eita Squared of the differences between the two groups of the study in the post measurements of the motivation scale towards English

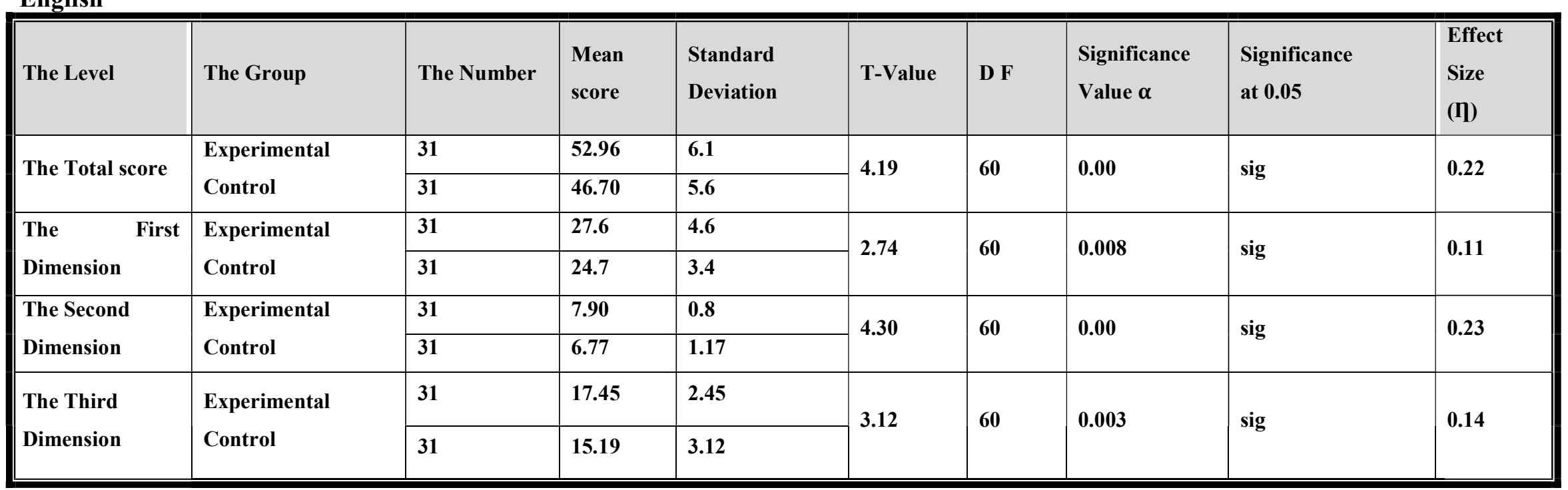

$*$ *Significant at $(\mathbf{0 . 0 5})$ level 
The table above shows that there is a statistically significant difference at $(0.05)$ level between the mean scores of the experimental group students' mean scores in their responses on the motivation scale and the control group in favor of the experimental group. $t$-Value for the differences between the two groups is calculated (4.19), Effect size is estimated (0.22).This is applied to both the results obtained for individual dimension and the total of all dimensions as a whole. Performance differences occurred between the experimental group and control group and positive improvement in favor of the experimental group are logically owing to successful intelligence theory and activities derived from it. Also because the former has been experiencing a relatively much more creative writing inspiring activities. Accordingly, the first hypothesis is verified, as both the t-value and the effect size are high . This clearly shows that the successful intelligence theory based program is highly effective in motivating secondary schoolers towards learning English. The previously mentioned result affirms that through the use of SITBP, participants practiced different writing activities employing effective teaching strategies that contributed in increasing the experimental group students' motivation towards English.

Fig (1). The differences between the experimental and the control groups in their post responses for the motivation scale towards English

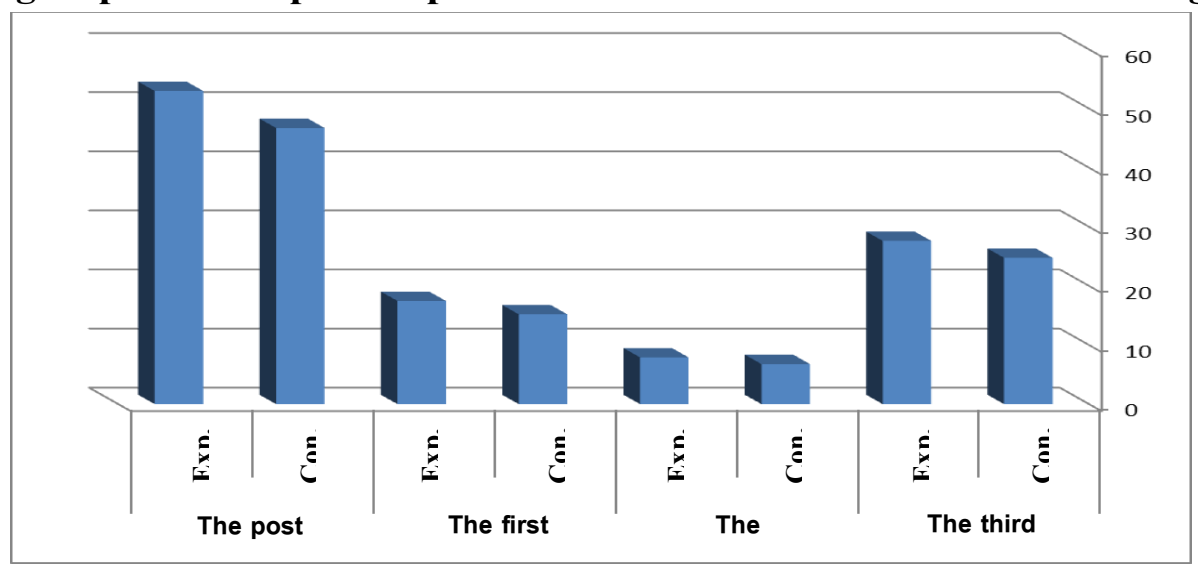

Hypothesis(2)

The third hypothesis stated "There is a statistically significant difference at $(0.05)$ level between the mean scores of the experimental group in the pre administration of the creative writing skills test and those of the post administration of the same test in favor of the post administration" is tested using the t-test. Mean scores, Standard 
deviations and t-test for paired samples were calculated for verifying the statistical significance.

Table (3) t- test Value for the differences between the total mean scores on the pre and post application of the creative writing skills test of the experimental group

\begin{tabular}{|c|c|c|c|c|c|c|c|c|}
\hline Skills & $\begin{array}{l}\text { The group } \\
\text { The } \\
\text { Experiment } \\
\text { al Group }\end{array}$ & $\mathbf{N}$ & $\begin{array}{l}\text { Mean } \\
\text { Score } \\
\text { s }\end{array}$ & $\begin{array}{l}\text { Standar } \\
\text { d } \\
\text { Deviatio } \\
\text { n }\end{array}$ & $\begin{array}{l}\text { D } \\
\text { F }\end{array}$ & $\begin{array}{l}\text { T- } \\
\text { Valu } \\
\text { e }\end{array}$ & $\begin{array}{l}\text { Significan } \\
\text { ce Value } \alpha\end{array}$ & $\begin{array}{l}\text { Significan } \\
\text { ce at level } \\
0.05\end{array}$ \\
\hline \multirow{2}{*}{\begin{tabular}{|l|} 
Creativ \\
e \\
Writin \\
g Skills \\
test \\
\end{tabular}} & $\begin{array}{l}\text { The pre } \\
\text { application }\end{array}$ & $\begin{array}{l}3 \\
1\end{array}$ & 9.67 & 6.42 & $\begin{array}{l}3 \\
\mathbf{0}\end{array}$ & \multirow{2}{*}{9.36} & \multirow{2}{*}{0.00} & \multirow{2}{*}{ Sig } \\
\hline & $\begin{array}{l}\text { The post } \\
\text { application }\end{array}$ & $\begin{array}{l}\mathbf{3} \\
\mathbf{1}\end{array}$ & 21.32 & 4.34 & $\begin{array}{l}3 \\
\mathbf{0}\end{array}$ & & & \\
\hline
\end{tabular}

Table (3) shows that there is a statistically significant difference at $(0.05)$ level between the mean scores of the pre-post application of the creative writing skills test of the experimental group in favor of the post measurement. This result proves that the creative writing skills of participants improved. This asserts the positive effect of the (SITBP) on developing their creative writing. Therefore, the third hypothesis of the study is verified.

These positive results may be retrieved to the major principle of the successful intelligence theory that asserts the necessity of discovering errors that students done during writing and gaining insights of their own strengths and weaknesses. Moreover, allowing them to avoid these errors next times and reinforcing their selfconfidence. In addition, this improvement may be due to the instructor's continous comments and feedback.

It is worth mentioining that, the previously reported result largely agrees with those of Sternberg (2005); Temizkan (2011); Ryan(2014); and Asri(2015) which confirmed the effectiveness of applying the successful intelligence theory principles and teaching teqniques in developing creatitity and creative writing skills among learners.

Hypothesis (3)

To test the third hypothesis: , "There is a statistically significant difference between the mean scores of the experimental group in the pre administration of the motivation scale and that of the post administration of the same scale in favor of the post administration", 
the following required measures were calculated.: Mean scores, standard deviations and t-test for paired samples were found out for making sure of the significance. The following table indicates the previously mentioned results concerning this hypothesis.

Table (4) $t$ test Value for the differences between the experimental group's pre- post measurements of the motivation scale towards English

\begin{tabular}{|c|c|c|c|c|c|c|c|c|}
\hline Skills & $\begin{array}{l}\text { The group } \\
\text { The } \\
\text { Experiment } \\
\text { al Group }\end{array}$ & $\mathbf{N}$ & $\begin{array}{l}\text { Mea } \\
\text { n } \\
\text { Score } \\
\text { S }\end{array}$ & $\begin{array}{l}\text { Standar } \\
\text { d } \\
\text { Deviatio } \\
\text { n }\end{array}$ & $\begin{array}{l}\text { D } \\
\text { F }\end{array}$ & $\begin{array}{l}\text { t- } \\
\text { Valu } \\
\text { e }\end{array}$ & $\begin{array}{l}\text { Significan } \\
\text { ce Value } \\
\alpha\end{array}$ & $\begin{array}{l}\text { Significan } \\
\text { ce at level } \\
0.05\end{array}$ \\
\hline \multirow{2}{*}{$\begin{array}{l}\text { Motivati } \\
\text { on Scale } \\
\text { towards } \\
\text { Learning } \\
\text { English }\end{array}$} & $\begin{array}{l}\text { The pre } \\
\text { application }\end{array}$ & $\begin{array}{l}3 \\
1\end{array}$ & 42.03 & 3.36 & $\begin{array}{l}3 \\
\mathbf{0}\end{array}$ & \multirow{2}{*}{9.09} & \multirow{2}{*}{$\mathbf{0 . 0 0}$} & \multirow{2}{*}{ Sig } \\
\hline & $\begin{array}{l}\text { The post } \\
\text { application }\end{array}$ & $\begin{array}{l}3 \\
1\end{array}$ & 52.96 & 6.06 & $\begin{array}{l}3 \\
\mathbf{0}\end{array}$ & & & \\
\hline
\end{tabular}

Table (4) shows there is a statistically significant difference at (0.05) level between the mean scores of experimental group's pre- and post measurement of the motivation scale in favor of the mean scores of the post measurement. This difference proves that the motivation level of the experimental group has been increased. Therefore, results related to the fourth hypothesis of this study demonstrate the presence of observable change in the participants' motivation. Again, this can be ascribed to reasons related to varying teaching methods, practicing different writing activities and continuous feedback. Thus; hypothesis four is verified and supported.

Fig. (2) The differences between the experimental group pre- post measurements on the motivation scale towards English

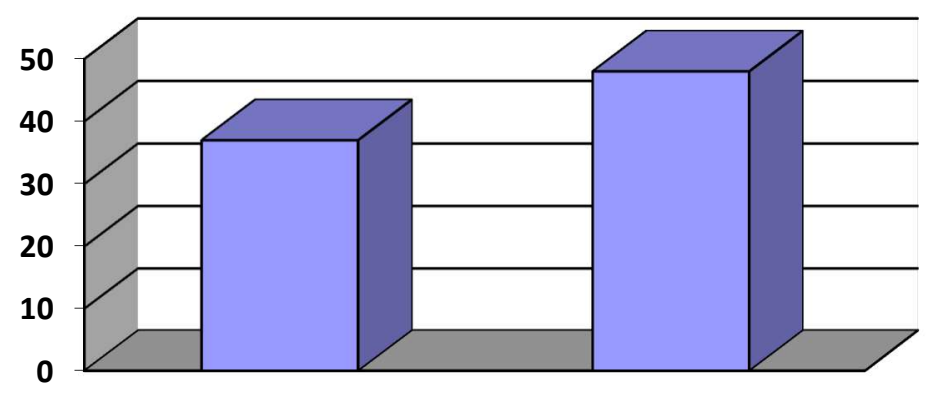

These results reveal that using Successful Intelligence Theory principles and the related activities contributedftein achieving an improvement in raising motivation level among the participants. This 
change can be attributed to using different writing activities; encouraging group working and free expression. Knowing that the purpose of the program and feedback was not for just evaluation and that the main aim was benefitting from those mistakes in order to avoid them afterwards. All these reasons helped in motivating the participants, reduced their fear and made them more enthusiastic to take part in writing activities.

The results reported in this part are in the same line with those of Kaufman\&Singer(2004); Sternberg (2005); Abou-Hemdan (2008); Mohammad \&Hussein (2013); Ryan (2014); Asri (2015); and Abu Jadou\& Al-Natour (2016) who proved and confirmed the effectiveness of using principles, related teaching methods such as brainstorming and applications of successful intelligence theory that encourage free expression in developing motivation among learners.

Recommendations

In the light of the results of the present study, the following recommendations can be given:

1-EFL reading skill courses should include Successful Intelligence Theory triarich dimensions(creative-analytical-practical) for developing motivation for critical reading skills among secondary stage students.

2-EFL teachers should be trained on applying successful intelligence theory in classes.

3-EFL student teachers courses should adopt applications and implications derived from successful intelligence theory in developing their motivation for learning novel and drama courses.

4- The main aim and principle of Successful Intelligence Theory which is stressing students' strengths and helping them to overcome their weaknesses and drawbacks in all instructional stages should be used.

5- Successful Intelligence Theory with its three dimensional steps should be used in teaching essay writing among EFL prospective teachers.

Suggestions for Further Research

In the light of the results and recommendations set before of the present study, the following are some suggestions for further research:

1-Further studies can be conducted to investigate the effect of successful intelligence theory on preparatory stage students' motivation .

2- Further studies can be conducted to investigate the effect of successful intelligence theory on motivating primary stage students towards learning English. 
A Program Based on the Successful ...... Marwa Gharib Ebrahim

3- Further studies can be conducted to investigate the effect of successful intelligence theory on motivating EFL prospective teachers' to write creatively.

4- Further studies can be conducted to investigate the effect of successful intelligence theory on developing primary stage students' writing skills.

5-Further studies can be done to examine the effect of successful intelligence theory on EFL student teachers' critical reading skills. 


\section{References}

Chenoweth, $\mathbf{N}$., \& Hayes, J. (2003). The inner voice in writing. Written Communication, Journal of Memory and Language, 27. Kluwer Academic.

Dornyei, Z. (2014).Motivation in second language learning. In M. CelceMurcia, D.M.Brinton and M. A. Snow (Eds.), Teaching English as a second or foreign language $\left(4^{\text {th }}\right.$ ed., pp. 518-531). Boston, MA: National Geographic Learning/ Cengage Learning.

Dornyei, Z.\& Csizer, K. \&Nemeth, N. Motivation, language attitudes and globalization. (2006).Library of Congress. British library.

Kaufman, S.(2004). Applying the theory of successful intelligence to psychotherapy training and practice. Imagination, cognition and personality. Vol. 23(4).

LO, C. (2009) An application of the Triarchic Theory of Intelligence to students of English in a Taiwanese university: Reflections of an action researcher. Doctoral thesis, Durham University. Available at Durham E-Theses Online: http://etheses.dur.ac.uk/61/.

Oxford, R .(1993): Research on second language learning strategies issues in second language teaching and learning .Annual review of Applied Linguistics.Vol.13.

Palos, R.\&, Maricutoiu, L.(2013). Teaching for Successful Intelligence Questionnaire (TSI-Q) - a new instrument developed for assessing teaching style. Journal of educational science and psychology, Vol. LXV No. 1

Saricaoglu, A \&Arikan,A.(2009).A study of successful intelligence and foreign language success and some variables. Journal of theory and practice in education.Ed.506218.

Sternberg, R. (2002). Successful intelligence. New York: Plume.

Sternberg,R\&Grigorenko,E. (2002)The Theory of Successful Intelligence as a Basis for Gifted Education. http://gcq.sagepub.com/content/46/4/265.

Sternberg, R. (2004). Successful intelligence as a basis for entrepreneurship. Journal of Business Venturing, 19,

Sternberg, R. \& Grigorenko, E. (2004). Successful intelligence in the classroom. Theory into practice, 4

Sternberg,R.(2005)The theory of successful intelligence.Revista Interamericana de Psicología/Interamerican Journal of Psychology - 2005, Vol. 39, Num. 2 .

Sternberg,R.\& Grigorenko, E .(2010). Teaching for Successful Intelligence:

Principles, Procedures, and Practices .Journal for the Education of the Gifted. 
A Program Based on the Successful ...... Marwa Gharib Ebrahim

Tigner, S. (2000). Triarchic theories of intelligence: Aristotle and Sternberg. History of Psychology, 3(2).

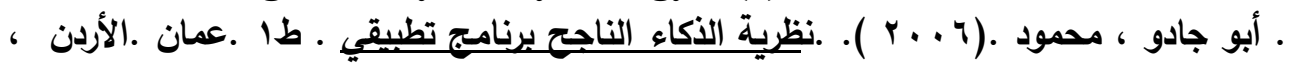
ديبونو للطباعة و النشر.

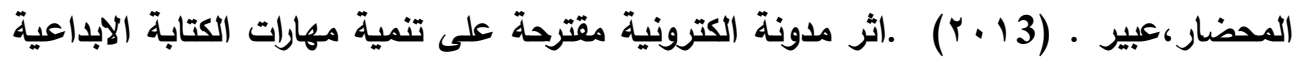
لاى طالبات المرحلة الثانوية.رسالة ماجستير غير منشورة. كلية التربية.جامعة الرياض.

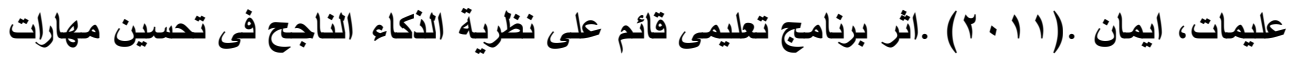

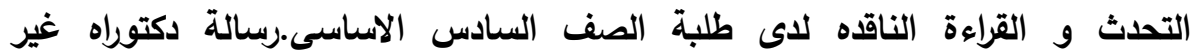

$$
\text { منشوره كلية التربية. جامعة اليرموك. }
$$

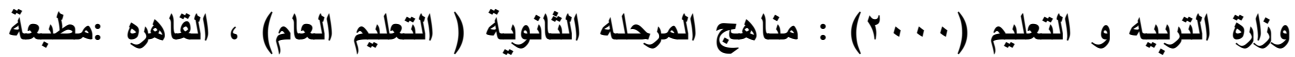

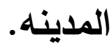


الملخص

كان الهاف من الاراسة الحالية هو تطوير دافع طلاب السنة الأولى الثانوية تجاه اللغة الإنجليزية. تم تطوير مقياس التحفيز والتحقق من صحته. كان التدخل التجريبي عبارة عن من

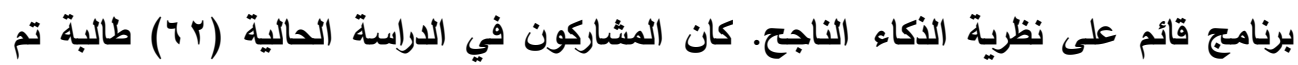
اختيارهم عن قصد من مدرسة الزهور الثانوية بالإسماعيلية. تم تقسيمه بالتساوي إلى مجموعتين (الضابطة والتجريبية). تم تطبيق مقياس التحفيز مسبقًا على المجموعتين. تم تدريس

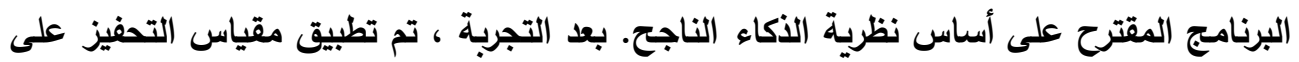
المجموعتين. تم جمع البيانات وتحليلها إحصائيا. أوضحت النتائج وجود فروق ذاءل ذات دلائة إحصائية بين متوسطي درجات المجموعتين الضابطة والتجرببية على المقياس لصالح طلاب المجموعة التجريبية. كما أوضحت النتائج وجود فروق ذات دلالة إحصائية بين متوسطي درجات الإدارات القبلي والبعدي للمجموعة التجريبية في أدائهم في مقياس التحفيز لصالح الإدارة البعدية.

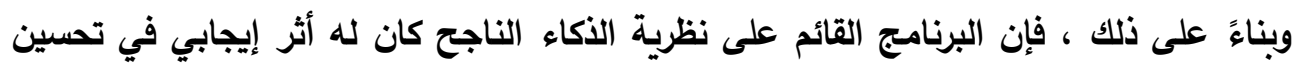
وتعزيز الدافع لاى طلاب المدارس الثانوية.

\section{Abstract}

The aim of the current study was to develop the first year secondary schoolers' motivation towards English. A motivation scale was developed and validated. The experimental intervention was a Successful Intelligence Theory based program. The participants of the current study were (62) female students who were purposefully chosen from El-Zohour secondary school in Ismailia. They were equally divided into two groups ( Control and Experimental). The motivation scale was pre administered to the two groups. The proposed program based on the Successful Intelligence Theory was taught. After the experiment the motivation scale was post administered to the two groups. The data were collected and statistically analyzed. The findings revealed that there were statistically significant differences between the mean scores of the control and experimental groups on the scale in favor of the experimental group students. Results also showed that there were statistically significant differences between the mean scores of the pre and post administrations of the experimental group in their performances in the motivation scale in favor of the post administration. Accordingly, it was concluded that the Successful Intelligence Theory based program had a positive effect on improving and enhancing motivation among secondary schoolers. 